\title{
Challenges and Opportunities in Cucumber Seed Production
}

\author{
Nakul Gupta ${ }^{1 *}$, Sunil Kumar ${ }^{1}$, S. K. Jain ${ }^{1}$, B. S. Tomar ${ }^{1}$, \\ Jogendra Singh and Vishwanath Sharma ${ }^{2}$ \\ ${ }^{1}$ ICAR-Indian Agricultural Research Institute, New Delhi, India \\ ${ }^{2}$ Rainforest Research Institute, Jorhat, Assam, India \\ *Corresponding author
}

\begin{abstract}
A B S T R A C T
Keywords

Cucumber seed, Under developed seed, Harvesting stage, Post-harvest ripening and Fruit load

Article Info

Accepted:

12 December 2020

Available Online:

10 January 2021

Quality seed is a vital input in agriculture that determines the potential of yield and quality of crop. Cucumber seed production has several issues such as formation of higher number of under developed seeds, sensitivity to micronutrient deficiency, exhibition of dormancy in freshly harvested seed etc. These above said issues directly affects seed quality and yield of cucumber. Optimization of harvesting stage and post-harvest ripening period, standardization of position of seed on plant and within the fruit, plant energy management through fruit load management and exogenous supply of chemicals/micronutrient etc. may be the best possible approaches to address these problems. In present review the different problems associated with cucumber seed production and possible approaches to overcome them are discussed.

\section{Introduction}

Vegetables play a vital role to meet food and nutritional security as they are more productive (per unit time and land area) than other crops. India is the second largest producer of vegetables in the world after China; with the production of $187.47 \mathrm{mt}$ and an area of 10.43mha [NHB, $2018\left(1^{\text {st }}\right.$ advance estimate)]. In India, the average vegetables productivity (17.96 t/ha) is much lower than other countries [China: $23.34 \mathrm{t} / \mathrm{ha}$; USA: 32.5 t/ha (FAO, 2012)]. Per capita land resources (0.121ha) in India, due to population pressure,

are shrinking, therefore, it is need of hour to ensure the higher production and productivity. India is blessed with diverse agro-climates, making it possible to grow a wide array of vegetables; of these cucurbitaceous vegetables with a number of edible species are the largest among the vegetable kingdom. It consists about 130 genera and 900 species including cucumber, bitter gourd, bottle gourd, ridge gourd, sponge gourd, ash gourd, snake gourd, squash, etc. The genus Cucumis contains nearly 40 species including three important ones (C. Sativus L [Cucumber], $C$. melo L [Cantloupe] and C. anguria L [West
\end{abstract}


Indian gherkin]), of these, cucumber is most important.

Cucumber, [Cucumis sativus $\mathrm{L},(2 \mathrm{n}=2 \mathrm{x}=14)$ ], belongs to the Cucurbitaceae and is indigenous to India. It is an ideal summer and kharif vegetable crop, chiefly grown for its edible tender fruits, preferred as salad ingredient, pickles, desert fruit and a cooked vegetable. The fruit is rich in minerals, thiamine, niacin and vitamin $\mathrm{C}(0.38 \mathrm{~g}, 0.3 \mathrm{mg}$, $0.2 \mathrm{mg}$, and $78 \mathrm{mg}$, respectively per $100 \mathrm{~g}$ of edible fruit). Fruit consist about $80 \%$ edible portion, which contains $95 \%$ water, $0.7 \%$ proteins, $0.1 \%$ fats, $3.4 \%$ carbohydrates, $0.4 \%$ fibers and $0.4 \%$ ash (Onimisi and Ovansa, 2015; Abbey et al., 2017). It is considered an ideal fruit for people suffering from jaundice and allied diseases as well useful in preventing constipation. Cucumber also helps in weight loss by regulating blood sugar as it is a low-calorie vegetable (Abbey et al., 2017). Among cucumber fruits, the peel and seeds, the most nutrient-dense part, contain phyto-nutrients, fibre and antioxidants, helps immunity and prevent cancer. Besides, seeds contain oil, which is helpful for brain development and smooth body; it is also being used in ayurvedic preparations (Robinson and Decker-walter, 1999). Various varieties of cucumber have been developed by public and private sector for growing in both kharif and summer seasons. There is a huge demand of quality seeds in cucumber. Several problems are associated in quality seed production of cucumber, which directly affects the quality and yield of seed (Fig 1). Consequently, Indian minimum germination standard for cucumber is only $60 \%$, which is very low to meet any international requirements (90\%) (Trivedi and Gunasekaran, 2013).

Therefore, an attempt has been made in present review to address the problems and opportunities in cucumber seed production.

\section{Challenges in seed production of cucumber}

\section{Formation of higher number of under developed seeds}

Formation of under developed or unfilled seed may result from lack of pollination and improper seed filling (insufficient assimilate transfer) (Gupta et al., 2021 a,b,c). Being cross pollinated, pollination in cucumber is mostly rely on insect activity, whereas seed filling depends on plant photosynthetic activity and source or sink ability.

\section{Sensitivity towards micronutrient defeciency}

Cucumber is very sensitive to micronutrient deficiency and problematic soils as it directly affects seed yield and quality (Frost and Kretehman, 1989). Besides, low efficiency of absorption of some micronutrients by plant from soil is a serious concern. The soil micronutrient deficiency not only limits the productivity of crops but also lowers seed/grain development and nutritional quality (Sanchez and Swaminathan, 2005; Singh, 2008; Phattarakul et al., 2012; Chen et al., 2017).

Six micronutrients viz manganese $(\mathrm{Mn})$, iron $(\mathrm{Fe})$, copper $(\mathrm{Cu})$, zinc $(\mathrm{Zn})$, boron $(\mathrm{B})$ and molybdenum (Mo) are known to be required by all plants (Welch et al., 1991). Among them $\mathrm{Fe}$ and $\mathrm{Zn}$ are very crucial for plant growth \& development; their deficiency is very common in various crops and soils (Marschner, 2012). Zinc deficiency in Indian soil is likely to increase from $49 \%$ to $63 \%$ by year 2025, as most of the marginal soils brought under cultivation have shown $\mathrm{Zn}$ deficiency (Arunachalam et al., 2013). In addition, micronutrient malnutrition, particularly $\mathrm{Zn}$ and Fe deficiency, affects over three billion people worldwide (Bouis, 2007). 
Exhibition of dormancy in freshly harvested seed

Another serious problem in cucumber seed is the presence of morpho-physiological dormancy (Jing et al., 2018; Patil, 2018). Fresh seeds extracted from cucumber exhibit high level of dormancy immediately after harvest.

\section{Opportunities and possible approaches}

The seed is the prime factor that determines the quantitative and qualitative characteristics of the crop. Therefore, more attention must be directed towards increasing seed yield and quality for seed growers' better economic returns. The following approaches can be opted to address the above said problems.

\section{Seed production under protected structure}

Seed quality is not only determined by its genetic background but also by the environmental conditions of the crop during seed development (Hampton et al., 2013). The significant differences in seed yield and quality attributes may be attributed to optimum growing conditions; relatively longer duration of maturity; with reduced biotic and abiotic stresses under protected environment than those to open field condition, which favours the better seed development and maturation (Gupta et al., 2021).

Variations in environmental factors such as space \& time, day \& night temperature, relative humidity of surrounding, soil moisture and soil nutrient status, etc directly affects the seed development and maturation process (Baskin and Baskin, 2014; Pagamas and Nawata, 2008). The lower temperature is known to enhance seed development (Duthion and Pigearie, 1991).
Optimization of harvesting stage and postharvest ripening period

It is well established that harvesting of seed at appropriate time or stage is most important to obtain better quality seed; maximum seed dry weight and quality are attained during physiological maturity, after which seed filling ends and germination \& vigour starts declining (Harrington, 1972). This hypothesis was supported by many researchers for a long time (Powell et al., 1984; Ellis et al., 1987; Alans and Eser, 2008), but later several studies (Zanakiset al., 1994; Elias and Copeland, 2001; Siddique and Wright, 2003), in many crops, showed its contradiction with harvest maturity. Gupta $e t$ al., (2021b) showed that the maximum seed quality (germination and vigour) during physiological maturity, which was at 40-45 DFP under open field and 50-60 DFP under protected condition. Whereas, the fruits harvested, on 45 DFP under open field and on 60 DFP under protected environment, registered significantly maximal fruits' and seeds' attributes viz fruits' weight, length, number of filled seeds/fruit and seed yield/ fruit may be attributed to continuous supply and accumulation of metabolites (food reserves) from mother plant to seed up to last maturation stage. Similarly, Ortola et al., (1988) reported that fruits gained maximal growth rate resulted into enhanced reserve supply toward the fruit until maturation, indicated an increase in sink potential of the fruit at final stage. Increase in fruit development attributes were positively correlated with seed development attributes $v i z$ seed length, width and weight due to food reserve accumulation. Seed size measured in terms of seed length and width reflected seed development and maturity.

Gupta et al., (2021b,d) observed that cucumber seeds attained germination ability on 25 DFP, which further increased 
substantially and reached maximum on physiological maturity and later declined slightly. All seed quality parameters were low in early harvested fruits due to presence of a greater number of immature and unfilled seeds with lesser food accumulate. At physiological maturity, pattern of accumulation of proteins, sugars, starch and oil contents in developing seeds clearly supported the increase in seed fresh and dry weights during seed maturation, and further demonstrated that seed filling in cucumber varieties continued up to later stages. Similar results on protein concentration were reported (Silva et al., 2017) in pumpkin hybrid, during seed maturation (up to 75 DFP). Decrease in seed water content followed by an increase in levels of reserve accumulates could contribute to gain the seed germination ability, as the reserve proteins supplies the amino acids for the formation of new proteins. The decrease in total soluble sugars and increase in starch contents, during seed development, may be due to the conversion of sugar into starch. Similar results were reported [Karkleliene et al., (2008); Pandya and Rao (2010) in pumpkin; Chandra and Keshavkant (2016) in Madhuca latifolia] seed development. Increase in starch content was also supported by Bhattacharya et al., (2002) as the starch is the seed reserve, required during the germination.

Fig.1 Problems in quality seed production of cucumber

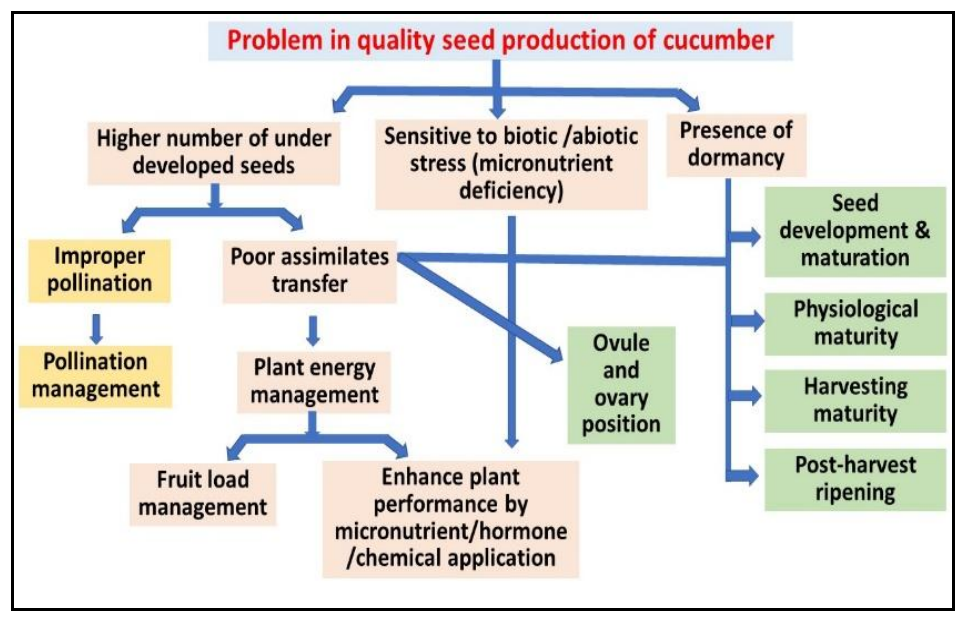

In cucumber, having indeterminate growth habit, practically difficult to trace all the fruits at harvest maturity with DFP; the fruit colour and complete plant wilt stage may be the better markers for identification of harvest stage during seed production of cucumber. Changes in fruit skin from green to yellowishbrown or brown, due to degradation of chlorophyll with prominent warts or nets due to rapid loss of moisture at final maturity may be the better marker of harvesting stage. Besides, the magnitude of seed chlorophyll fluorescence may be used as a marker for assessing the time of optimal harvest for cucumber seeds (Jing et al., 2000). Previously, several morphological and physiological indicators have been identified to assess the physiological and harvest maturity in many crops viz fruit and seed colour, seed moisture content, seed dry weight, germination and vigour (Elias and Copeland, 2001).

Stages of fruit harvest in combination with post-harvest ripening period significantly affected the seed development and yield attributes. Increase in seed yield viz1000-seed weight, seed fresh and dry weights may be 
due to seed as sink keep on receiving the accumulates with the advancement of seed maturity during seed development and/or post-harvest ripening period (within a fruit) (Gupta et al., 2021d; Vinod et al., (2014a,b)). However, an increase in filled seeds per fruit during PHR indicated the reshuffling of accumulates towards under developed seeds.

The increase in the total proteins, even after harvest, may be due to the continuation of metabolic processes (ie inter-conversion of free amino acids) within the plant cells. Additionally, the reduced activity of the hydrolytic enzymes (proteases and amylases) helps the fruit and in turn seeds, in accumulating the proteins and starch during the later stages of ripening (Stanley, 1998). Increase in accumulates during PHR may be due to transfer of assimilates from pulpy fruit to seeds.

Seed composition changes may be attributed to the development of bolder seeds, which directly or indirectly attributed to the increase in seed quality (viz seed germination and vigour) during PHR in cucumber (Gupta et al., 2021d); in pumpkin (Vinod et al., 2014b; Silva et al., 2017) Improved vigour in PHRseeds may also be attributed to better seed longevity/storability (Alan and Eser, 2008; Passam et al., 2010).

\section{Standardization of seed position on plant and within fruit}

The significantly different performance of seeds was observed from three fruit segments indicated that seeds within a fruit from different segments may not be of the similar age, as they do not mature at the same rate and time (Nielsen, 1996; Gupta et al., 2021a). This may probably due to pollen grain germination, pollen tube growth, zygote formation, seed development and maturation may not occur at the same rate and time
(Silvertown 1984; Delph et al., 1998). Normally, it is presumed that ovules located closer to the point of entry of pollen tubes will present a lower probability of abortion, whereas those found farther from the entry point will present a higher probability of abortion (Vinod et al., 2015). Thus, seeds from advantageous ovule positions (viz the stylar and middle segment of a fruit) exhibit higher seed dry weights and quality, whereas seeds from disadvantaged positions (viz the peduncular end of a fruit) either exhibit low quality or fail to reach maturity. Gupta et al., (2021a) also observed the variation in seed dry weights, seed quality and yield, probably due to higher assimilate supply (TSS, TSP, total starch and oil contents) in seedfrom middle and stylar segments of fruit.

On the other hand, cylindrical shape of fruit may also favours the development of seeds and proper supply of assimilates in wider space of middle segment than those to narrow end of peduncular segment. seeds from stylar and/or middle fruit segment had temporal and spatial advantages in receiving the vigorous pollen and garnering resources than those seeds from peduncular segment. Further, morphological, physiological and biochemical assays showed that the seeds obtained from middle and stylar segments of fruit were superior in quality and yield than peduncular segment. Hence, it could be recommended that optimum quality seeds in cucumber be harvested from middle and/or stylar segments; being seeds closer to style have the higher probability of seed setting than peduncular end.

\section{Enhancing pollination efficiency}

Pollination efficiency can be enhanced by arranging the frequent visits of insect pollinators. Which could be done by placing the bee hives (2-3 per ha or $1000 \mathrm{~m}^{2}$ protected structure). Besides pollination can be ensured 
by conducting hand pollination (Gupta et al., 2021).

\section{Plant energy management}

\section{Fruit load or fruit retention management}

Fruit retention is the number of fruits allowed to mature on the mother plant from the fruit set. Allowing more number of fruits on mother plant may result in higher seed setting with poor seed quality, whereas less number of fruits improved the quality of seed with compromised seed yield. Cucumber plants produce sufficient number of female flowers and more than required number of male flowers per vine in one growing season. But still pollination of even all the female flowers does not convert all the pollinated ovaries into mature fruit.

The cucurbits plants itself have an inbuilt mechanism of fruit set inhibition to regulate the fruit load per plant. Presence of older developing fruits prevents the younger ovaries from seed setting (Baniel et al., 2008). The photosynthetic activities of developing fruits and seeds do not produce enough resources to support their own development.

The first fruit formed on the basal node of avine has larger share in photosynthates than the subsequent fruit formed on the upper node. Thus, in cucurbits, the first formed fruits are bigger and they have suppressing effect on the fruits formed subsequently.

Although, many fruit and seed development attributes were higher with retention of one fruit per vine, but retention of two fruits per vine gave higher seed yields without compromising seed quality. Whereas, the three fruit loads per vine recorded significantly poor performance (seed yield \& quality) (Gupta et al., (2021c).

\section{Application of micronutrient}

Various methods can be opted for application of micronutrient such as soil application, foliar application and seed priming or coating. Foliar application of micronutrients especially in nano form was reported to be more effective in accessing nutrients for plants to achieve higher quality and yield (Hemantaranjan, 1988; Jalali et al., 2017). Gupta (2020) reported the positive impact of foliar application of $\mathrm{Zn}$ - and Fe- nano-paticles on physiological and biochemical parameters of cucumber seed, which finally resulted in enhanced seed quality and yield.

Similarly, various workers have documented the biological effects of $\mathrm{Zn}$ and Fe nanoparticles (NPs) foliar applications in mung bean, pomegranate, barley, maize, sunflower and wheat (Dhoke et al., 2013; Davarpanah et al., 2016; Janmohammadi et al., 2016a,b; Jalali et al., 2017; Torabian et al., 2017; Deshpande et al., 2018) plants. Nano-particles due to tiny size (at least two dimensions less than 100nm), exhibit many physio-chemical properties (higher surface area, reactivity, solubility, penetration capacity, surface/volume ratio), which makes them better for application in agriculture, as required in low quantity than those to their bulk compounds (Raimondi et al., 2005; Sharma et al., 2012; Hett et al., 2004). Use of NPs through foliar applications have the advantage over commercial fertilizers and other applications, as they show controlled and targeted delivery of micronutrients and applied in smaller quantity.

\section{References}

Abbey BW, Nwachoko N and Ikiroma GN (2017) Nutritional value of cucumber cultivated in three selected states of Nigeria Biochemistry and Analytical Biochemistry $\quad 6: \quad 328$ 
DOI:10.4172/2161-1009.1000328

Alan O and Eser B (2008) The effect of fruit maturity and post-harvest ripening on seed quality in hot and conic pepper cultivars Seed Science and Technology 36: 467-74

Arunachm P, Kannan P, Balasubramaniyan P, Prabukumar $G$ and Prabhaharan J (2013) Response of groundnut (Arachis hypogaea L) genotypes to biofortification through soil fertilization of micronutrient in Alfisol condition Annual Report of Dryland Agricultural Research Station, Chettinad, India 7: 254-68

Baniel A, Saraf-levy T and Perl-treves R (2008) How does the first fruit inhibit younger fruit set in cucurbits? In: M Pitrat (ed) Proceedings IXth EUCARPIA meeting on genetics and breeding of Cucurbitaceae, INRA, Avignon (France), May 21-24, 2008 pp 597-601

Baskin CC and Baskin JM (2014) Seeds: Ecology, Biogeography and Evolution of Dormancy and Germination ( $2^{\text {nd }}$ edn $)$ Academic/Elsevier, San Diego, CA, USA pp 1600

Bhattacharya A, Nagar PK and Ahuja PS (2002) Seed development in Camellia sinensis Seed Science Research 12: 3946

Bouis HE (2007) The potential of genetically modified food crops to improve human nutrition in developing countries Journal of Development Studies 43: 7996

Chandra J and Keshavkant S (2016) Physiological and biochemical changes during seed development and maturation in madhuca latifolia roxb Bangladesh Journal of Botany 45(2): 335-43

Chen XP, Zhang YQ, Tong YP, Xue YF, Liu DY, Zhang W, Deng Y, Meng QF, Yue SC, Yan P and Cui ZL (2017)
Harvesting more grain zinc of wheat for human health Scientific Reports 7(1): 7016 DOI: 10.1038/s41598-017-074842

Davarpanah S, Tehranifar A, Davarynejad G, Abadia J and Khorasani R (2016) Effects of foliar applications of zinc and boron nano-fertilizers on pomegranate (Punica granatum cv Ardestani) fruit yield and quality Scientia Horticulturae 210: $57-4$

Delph LF, Weinig C and Sullivan K (1998) Why fast-growing pollen tubes give rise to vigorous progeny: The test of a new mechanism Proceedings Royal Society of Biological Sciences pp 935-39

Deshpande P, Dapkekar A, Oak M, Paknikar K and Rajwade J (2018) Nanocarriermediated foliar zinc fertilization influences expression of metal homeostasis related genes in flag leaves and enhances gluten content in durum wheat PLOS ONE 13(1): e0191035 DOI:10.1371/journal.pone.0191035

Dhoke SK, Mahajan P, Kamble R and Khanna A (2013) Effect of nanoparticles suspension on the growth of mung (Vigna radiata) seedlings by foliar spray method Nanotechnology Development $3:$ DOI:10.4081/nd.2013.e1

Duthion C and Pigearie A (1991) Seed lengths corresponding to the final stage in seed abortion of three grain legumes Crop Science 31: 1579-83

Elias SG and Copeland LO (2001) Physiological and harvest maturity of canola in relation to seed quality Agronomy Journal 93(5): 1054-58

Elias SG and Copeland LO (2001) Physiological and harvest maturity of canola in relation to seed quality Agronomy Journal 93(5): 1054-58

Ellis RH, Hong TD and Roberts EH (1987) The development of desiccation tolerance and maximum seed quality 
during seed maturation in six grain legumes Annals of Botany 59: 23-29

FAO (2012) FAOSTAT Data Base Collection Food and Agriculture Organization of the United Nations, Romehttp://www.fao.org/faostat

Frost DJ and Kretehman DW (1989) Calcium deficiency reduces cucumber fruit and seed quality Journal of the American Society for Horticultural Science 114: $552-56$

Groot SPC (2000) Cucumber (Cucumis sativus L) seed performance as influenced by ovary and ovule position Seed Science Research 10: 435-45

Gupta N (2020) Study on quality seed production in cucumber (Cucumis sativus L)PhD Thesis PG School IARI, New Delhi, India

Gupta N, Jain SK and Tomar BS (2021a) Physio-biochemical changes associated with spatial differences of ovules in cucumber (Cucumis sativus L) fruit under open field and protected environments. Vegetable Science (accepted)

Gupta N, Jain SK, Tomar BS, Anand A, Singh J and Singh AK (2021b) Morpho-physiological and biochemical changes during seed development in cucumber (Cucumissativus L) under protected and open field environments. Indian Journal of Agricultural Sciences (accepted)

Gupta N, Jain SK, Tomar BS, Anand A, Singh J and Singh AK (2021c) Physiological and biochemical changes associated with fruit load per vine and seed quality in cucumber (Cucumis sativus L) under open field and protected environments. Indian Journal of Horticulture (accepted)

Gupta N, Kumar S, Jain SK, Tomar BS, Singh J and Sharma V (2021d) Effects of stage of harvest and post-harvest ripening of fruits on seed yield and quality in cucumber grown under open field and protected environments. International Journal of Current Microbiology and applied Science (accepted)

Hampton JG, Boelt B, Rolston MP and Chastain TG (2013) Effects of elevated $\mathrm{CO}_{2}$ and temperature on seed quality Journal of Agriculture Science 151: 154-62

Harrington JF (1972) Seed storage and longevity In: TT Kozlowski (ed) Seed Biology Vol III AcademicPress New York, USA pp 145-45

Hemantaranjan A and Gray OK (1988) Iron and zinc fertilization with reference to the grain quality of Triticum aestivum $\mathrm{L}$ Journal of Plant Nutrition 11: 1439-50

Hett A (2004) Nanotechnology: small matters, many unknown Swiss Re Publications pp 11-13

Jalali M, Ghanati F, Modarres-sanavi AM and Khoshgoftarmanesh AH (2017) Physiological effects of repeated foliar application of magnetite nanoparticles on maize plants Journal of Agronomy and Crop Science pp 1-10

Jing HC, Bergervoet JHW, Jalink H, Klooster M, Du SL, Bino RJ, Hilhorst HWM and

Karkleliene R, Viskelis P and Rubinskiene M (2008) Growing, yielding and quality of different ecologically grown pumpkin cultivars Sodininkystte Ir Darzininkyste 27(2): 401-10

Marschner H (2012) Mineral Nutrition of Higher Plants Academic Press, London pp 347-64

NHB (2018) National Horticulture Board Annual Report 2018-19 http://nhb.gov.in

Nielsen (Bob) RL (1996) Purdue Pest Management and Crop Production Newsletter, West Lafayette 47: 9041150

Onimisi AO and Ovansa JU (2015) Comparative studies on nutritional 
values of four varieties of cucumber Proceedings International Conference on Latest Trends in Food, Biological Conference and Ecological Sciences (ICLTFBE'15) Dubai (UAE) 11-12

Ortola AG, Monerri C and Guardiola JL (1988) Estimulacion del desarrollo del frutoen el mandarino Satsuma mediaute la aplicacion de acidonaftalenacetico Actas de Horticultura 1: 22-27

Pagamas P and Nawata E (2008) Sensitive stages of fruit and seed development of chili pepper (Capsicum anпиum $\mathrm{L}$ var Shishito) exposed to high temperature stress Scientia Horticulturae 117: 21-5 DOI:10.1016/j.scienta.2008.03.017

Pandya JB and Rao TVR (2010) Analysis of certain biochemical changes associated with growth and ripening of pumpkin fruit in relation to its seed development Journal of Pure and Applied Sciences 18: $34-9$

Passam HC, Theodoropoulou S, Karanissa T and Karapanos IC (2010) Influence of harvest time and after-ripening on the seed quality of eggplant Scientia Horticulturae 125(3): 518-20

Patil S (2018) Optimizing seed yield and quality in cucumber (Cucumis sativus cv Pusa Barkha) MSc Thesis PG School IARI, New Delhi, India pp 46-47

Phattarakul N, Rerkasem B, Li LJ, Wu LH, Zou CQ, Ram H, Sohu VS, Kang BS, Surek H, Kalayci $M$ and Yazici A (2012) Biofortification of rice grain with zinc through zinc fertilization in different countries Plant and Soil 361: 131-41

Powell AA, Don R, Haigh R, Phillips G, Tonkin JHB and Wheaton OE (1984) Assessment of repeatability of controlled deterioration vigour test both within and between laboratories Seed Science and Technology 12: 421-27

Raimondi F, Scherer GG, Kotz R and Wokaun A (2005) Nanoparticles in energy technology: Examples from electrochemistry and catalysis Angewandte Chemie (International edn in English) 44: 2190-209

Robinson RW and Decker-walters DS (1999) Cucurbits CABI International, Wallingford, Oxford, UK pp 226

Sanchez PA and Swaminathan MS (2005) Hunger in Africa: The link between unhealthy people and unhealthy soils The Lancet 365: 442-44

Sharma V, Ashutosh K and Alok D (2012) Nanomaterials: Exposure, effects and toxicity assessment Proceedings of the National Academy of Sciences, India Section B: Biological Sciences 82(S1): 3-11 DOI:10.1007/s40011-012- 0072-7

Siddique AB and Wright D (2003) Effects of time of harvest at different moisture contents on seed fresh weight, dry weight, quality (viability and vigour) and food reserves of peas (Pisum sativum L) Asian Journal of Plant Sciences 2(13): 983-92

Silva PP, Barros ACSA, Dias DCFS, Sekita MC and Nascimento WM (2017) Biochemical changes in hybrid pumpkin seeds at different stages of maturation Revista Ciência Agronômica 48(3): 558-64

Silvertown WJ (1984) Phenotypic variety in seed germination behaviour: The ontogeny and evolution of somatic polymorphism in seeds The American Naturalist 124(1): 1-16

Singh MV (2008) Micronutrient deficiencies in crops and soils in India. In: BJ Alloway (ed) Micronutrients Deficiencies in Global Crop Production ( $4^{\text {th }}$ edn) Springer Reading UK pp 93125

Stanley JK (1998) Post-harvest Physiology of Perishable Plant Products CBS Publishers and Distributors New Delhi pp 143-256

Trivedi RK and Gunasekaran M (2013) 
Indian Minimum Seed Certification StandardsThe Central Seed Certification Board, Department of Agriculture \& Co-operation, Ministry of Agriculture, Government of India, New Delhi pp 237-38

Vinod K (2012) Optimization of quality seed production in pumpkin cv Pusa Hybrid-

1. PhD Thesis PG School IARI, New Delhi, India pp 49-56

Welch RM, Allaway WH, House WA and Kubota J (1991) Geographic distribution of trace element problems In: JMortvedt and WI Madison (eds) Micronutrients in Agriculture Soil Science Society of America pp 31-57

Zanakis GN, Ellis RH and Summerfield RJ (1994) Seed quality in relation to seed development and maturation in three genotypes of soybean (Glycine max) Experimental Agriculture 30(2): 13956.

\section{How to cite this article:}

Nakul Gupta, Sunil Kumar, S. K. Jain, B. S. Tomar, Jogendra Singh and Vishwanath Sharma. 2021. Challenges and Opportunities in Cucumber Seed Production. Int.J.Curr.Microbiol.App.Sci. 10(01): 2135-2144. doi: https://doi.org/10.20546/ijcmas.2021.1001.245 